\title{
Paraneoplastic Limbic Encephalitis Caused by Ovarian Teratoma with Autoantibodies to Glutamate Receptor
}

\author{
Sadahisa Okamoto ${ }^{1}$, Teruyuki Hirano ${ }^{1}$, Yukitoshi Takahashi ${ }^{2}$, Taro Yamashita ${ }^{1}$, \\ Eiichiro Uyama ${ }^{1}$ and Makoto Uchino ${ }^{1}$
}

\begin{abstract}
We report a rare case of paraneoplastic limbic encephalitis with autoantibodies to glutamate receptor (GluR) in the cerebrospinal fluid (CSF). The 35-year-old woman with consciousness disturbance was diagnosed initially as non-herpetic encephalitis. Her signs and symptoms improved with acyclovir and steroid pulse therapy. However, after the treatment, an ovarian tumor was discovered, and we detected autoantibodies to GluR in the CSF. A possible association between the ovarian teratoma and GluR is suggested.
\end{abstract}

Key words: paraneoplastic limbic encephalitis, ovarian teratoma, glutamate receptor

(DOI: 10.2169/internalmedicine.46.6466)

\section{Introduction}

Paraneoplastic limbic encephalitis (PLE) is a relatively rare, remote, non-metastatic neurological complication of carcinoma. PLE occurs subacutely in association with specific neuronal antibodies (1). In a Japanese survey, nonherpetic acute limbic encephalitis (non-herpetic ALE) was identified as a new subgroup of limbic encephalitis with the spectrum that includes herpes simplex encephalitis (HSE) and PLE $(2,3)$. Antibodies to glutamate receptor (GluR) in the central nervous system (CNS) are reported to be an important autoimmune factor in Rasmussen's encephalitis, epilepsia partialis continua, non-herpetic acute encephalitis, acute encephalitis and paraneoplastic cerebellar ataxia (4-7). Here, we describe a case of PLE associated with an ovarian teratoma and detect autoantibodies to GluR and an elevation of interleukin-6 (IL-6) in the CSF. This case illustrates a potential association between an ovarian teratoma and autoantibodies.

\section{Case Report}

A 35-year-old woman with confusion and impaired consciousness was transferred from a local general hospital to the neurology department of Kumamoto University Hospital.
She had no symptoms until September 2004, she complained of headache, fever and short-term memory loss. Her symptoms gradually worsened. In the first hospital, the patient was diagnosed with viral encephalitis. Acyclovir $(1.5 \mathrm{~g}$ per day) was administered intravenously for 11 days and $500 \mathrm{mg}$ of methylprednisolone per day was added for 3 days. However, her condition did not improve, and she developed delusional thinking and auditory hallucinations.

When she was transferred from the first hospital, her temperature was $35.8^{\circ} \mathrm{C}$. She showed psychiatric depression and an agitated confusional state with severe impaired attention, orientation and persistence of the depressive state. Physical examination revealed no abnormalities. Palpation of the abdomen revealed no mass. Neurological examination and systemic examination were entirely normal.

The results of laboratory tests including blood counts, biochemical tests, and C-reactive protein were within normal range. There were no evident endocrine or metabolic abnormalities. Tests for antinuclear antibodies were negative. Her CSF pressure was $75 \mathrm{mmH}_{2} \mathrm{O}$. The fluid was clear and contained 15 cells $/ \mu \mathrm{l}, 66 \mathrm{mg} / \mathrm{dl}$ of glucose, $34.7 \mathrm{mg} / \mathrm{ml}$ of protein, $2.96 \mathrm{mg} / \mathrm{ml}$ of IgG, $14.9 \mathrm{pg} / \mathrm{ml}$ of IL-6 (normal $<9.7$ ), $3.1 \mathrm{pg} / \mathrm{ml}$ of IL-4 (<11.6), $2.6 \mathrm{pg} / \mathrm{ml}$ of IL-2 $(<4.6), 2.8 \mathrm{pg} /$ $\mathrm{ml}$ of tumor necrosis factor- $\alpha(<6.2), 4.1 \mathrm{pg} / \mathrm{ml}$ of IL-10 $(<$ $6.1)$ and $7.1 \mathrm{pg} / \mathrm{ml}$ of interferon- $\gamma(<46.6)$. Microscopic examinations of CSF for tumor cells and microorganism were

\footnotetext{
${ }^{1}$ Department of Neurology, Graduate School of Medical Sciences, Kumamoto University, kumamoto and ${ }^{2}$ National Epilepsy Center, Shizuoka Institute of Epilepsy and Neurological Disorders, shizuoka

Received for publication December 26, 2006; Accepted for publication March 13, 2007

Correspondence to Dr. Sadahisa Okamoto, s-okamoto@fc.kumamoto-u.ac.jp
} 


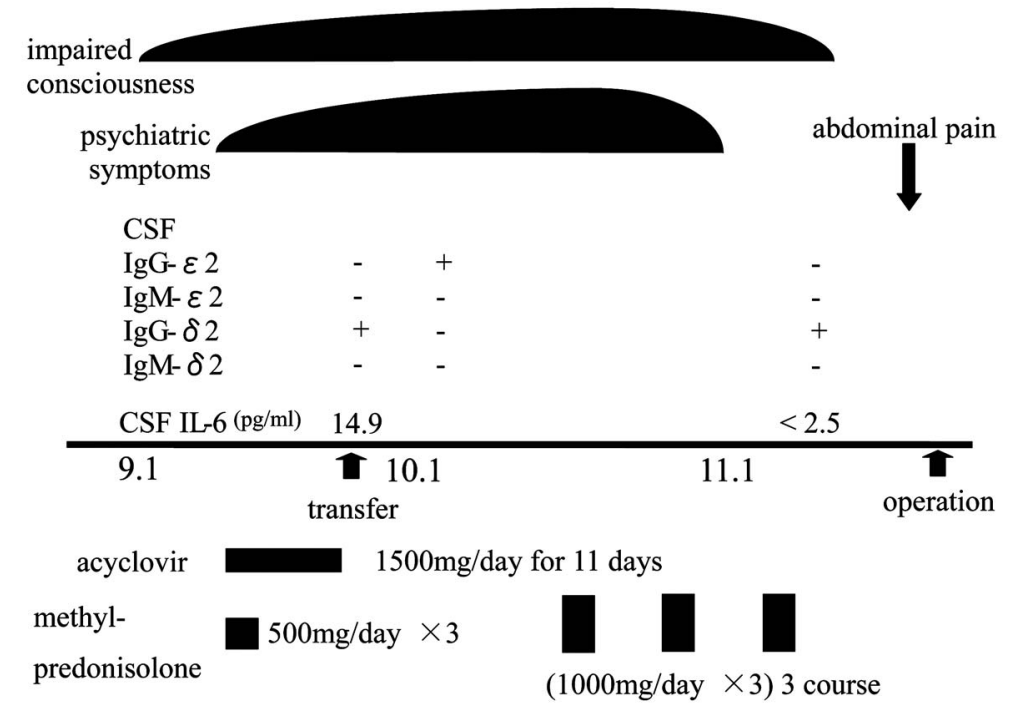

Figure 1. Clinical course. IgG- $\varepsilon 2$, IgM- $\varepsilon 2$, IgG- $\delta 2$, IgM- $\delta 2$ : IgG and IgM autoantibodies to GluR $\varepsilon 2$ or $\delta 2$.

negative, and cultures yielded no growth. There was no remarkable elevation of anti-viral antibody titers including mumps, rubella, echo, and varicella-zoster virus in paired serum samples. Polymerase chain reaction (PCR)-based tests for herpes simplex virus (HSV), cytomegalovirus (CMV), Epstein-Barr virus (EBV) and human herpesvirus-6, 7 (HHV-6, 7) in the CSF were negative. Magnetic resonance imaging (MRI) of the brain was normal.

\section{Clinical course (Fig. 1)}

The consciousness impairment progressed. The patient was restless, constantly in motion and talked incessantly and incoherently. We inferred that the limbic system was the locus for her psychiatric symptoms. A diagnosis of nonherpetic acute limbic encephalitis was made on the basis of negative findings of herpetic group (HSV, CMV, EBV) on PCR and slightly elevated IL-6 in the CSF. PLE was thought to be unlikely in the absence of a positive cytologic examination and with a normal range of tumor markers such as neuron specific enolase and soluble IL-2 receptor. In addition, a previous gynecological examination performed five months before this administration showed no significant abnormalities and the uterus and the adnexal structures were normal in size and echotexture. Methylprednisolone (1,000 $\mathrm{mg}$ per day) was administered intravenously for a 3 days course three times. Risperidone ( $2 \mathrm{mg}$ per day) and olanzapine (10 $\mathrm{mg}$ per day) were also used to manage her confusion. After three courses of methylprednisolone, symptoms regressed and the CSF IL-6 level returned to normal range. A follow-up MRI also showed normal findings.

The patient's condition was improving, but, at three weeks after treatment, a tumor was discovered in her lower abdomen. A pelvic MRI revealed a solid tumor filling the pelvic cavity. Tumor markers associated with ovarian tumor showed $55 \mathrm{U} / \mathrm{ml}$ of CA125 and $170 \mathrm{U} / \mathrm{ml}$ of CA19-9. She had a sudden onset of high fever and abdominal pain in the
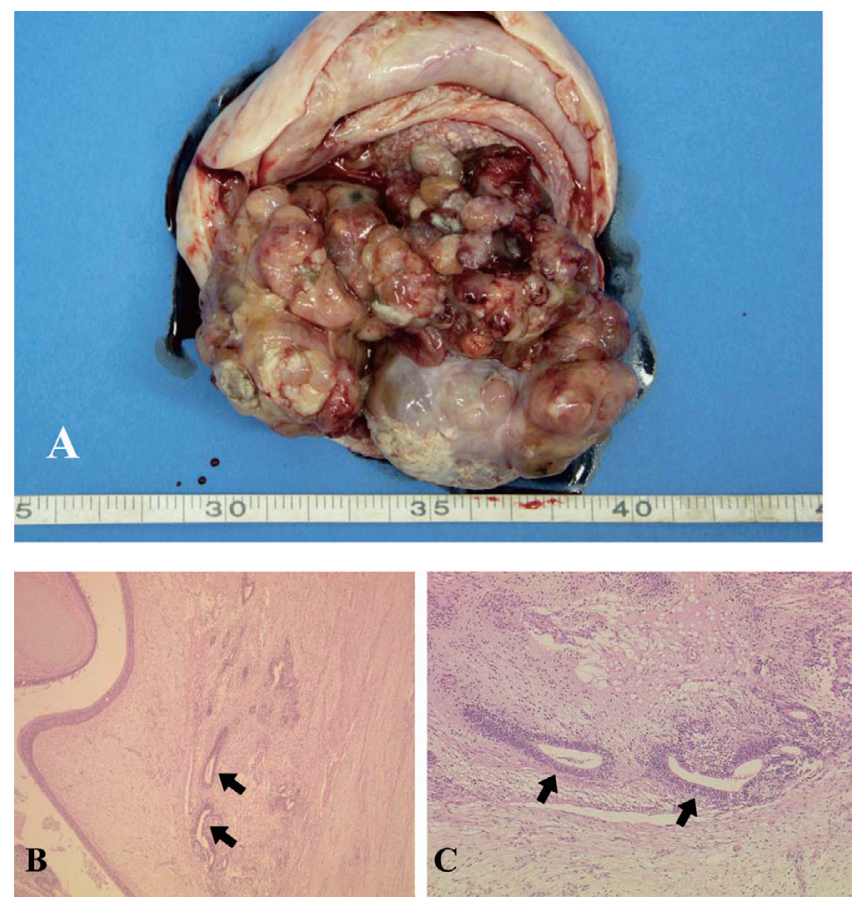

Figure 2. Pathological findings of ovarian tumor: (A) The tumor was solid and included hair and cartilage on macroscopic examination. (B), (C) Neuroepithelial cells (arrows) are shown (B,C: HE stain, $\mathrm{B} \times 40, \mathrm{C} \times 100)$.

lower abdomen a few days later. The resistance of the abdominal wall increased and moderate tenderness was elicited. The diagnosis was panperitonitis due to rupture of the ovarian tumor. She had an emergency right salpingooophorectomy. There was no apparent metastasis to the pelvic wall. The tumor was solid and included hair and cartilage. The pathologic diagnosis was an immature teratoma of grade 2 with an immature neuroepithelial component (Fig. 2). After surgical resection, she received chemotherapy. The patient is currently well at 2 years after surgical treat- 


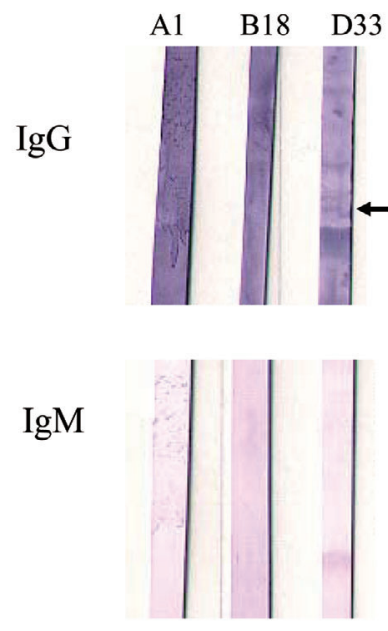

Day 1
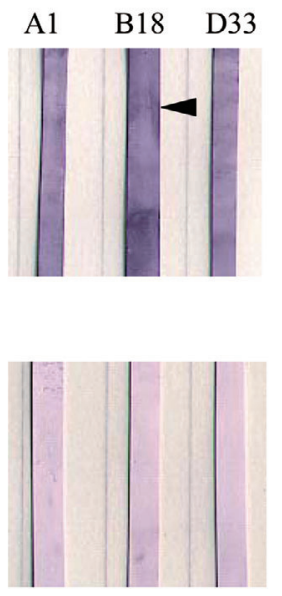

Day 11
Figure 3. Detection of autoantibodies to whole molecule GluR $\varepsilon 2$ and $\delta 2$ subunit in the cerebrospinal fluid samples from this patient. Data for IgG and IgM autoantibodies are shown. A1 = control strip. ; B18 = strip of nitrocellulose membrane containing whole GluR $\varepsilon 2$ proteins reacted with CSF of this patient.; D33 = strip of nitrocellulose membrane containing whole GluR $\delta 2$ proteins reacted with CSF of this patient. arrowhead $=$ whole molecule of GluR $\varepsilon 2$ (about 180 kd), arrow $=$ whole molecule of GluR $\delta 2$ (about $100 \mathrm{kd}$ ), stained with patient's autoantibodies followed by alkaline phosphate-labeled second antibodies. GluR IgG- $\varepsilon 2$ and IgG$\delta 2$ autoantibodies were detected in the CSF samples at the first and 11th day of admission, respectively. ment with no evidence of recurrence of the tumor. Psychotropic drugs were gradually tapered in 4 weeks and discontinued. She has neither physical nor mental disabilities.

After surgery, to clarify the potential association between encephalitis and ovarian tumor, anti-Hu, Yo, Ri, Ma, Ta, Tr and Amphyphysin antibodies in the patient's CSF that had been stored before treatment were tested. All antibodies were negative. However autoantibodies to the glutamate receptor (GluR) subunits epsilon $(\varepsilon)-2$ and delta $(\delta)-2$ were detected in the serum and CSF (Fig. 3). A sample of ovarian tumor extract was tested with immunoblotting analysis. However expression of GluR $\varepsilon 2$ or GluR $\delta 2$ was not confirmed by immunoblot analysis using antibodies against GluR $\varepsilon 2$ or GluR $\delta 2$.

\section{Discussion}

The present patient suffered from limbic encephalitis associated with an immature ovarian teratoma. She had autoantibodies to GluRs and elevated IL-6 level in the CSF. These findings suggest that the neurological symptoms were attributed to the paraneoplastic autoimmune mechanisms.

Recently, six cases of ovarian teratoma (mature: 2 cases, immature: 4 cases) in association with PLE have been reported. The clinical characteristics of literature cases including the present case are summarized in Table 1 (8-13). There were cases of mild CSF pleocytosis without infectious etiology and no antineural antibodies except in one case (8). Neurological symptoms of all six cases including ours improved or completely resolved after treatment.

Neurological symptoms in most patients did not improve after the first course of steroid pulse therapy, but those pa-

Table 1. Literature Cases of Paraneoplastic Encephalitis with Ovarian Teratoma

\begin{tabular}{|c|c|c|c|c|c|c|c|}
\hline Patients & $\begin{array}{c}\text { Fadare et } \\
\text { al. }[8]\end{array}$ & $\begin{array}{c}\text { Nokura et al. } \\
{[9]}\end{array}$ & $\begin{array}{c}\text { Okamura et } \\
\text { al. }[10]\end{array}$ & $\begin{array}{c}\text { Taylor et al. } \\
{[11]}\end{array}$ & $\begin{array}{c}\text { Aydiner et al. } \\
{[12]}\end{array}$ & $\begin{array}{c}\text { Munakata et } \\
\text { al. [13] }\end{array}$ & Present case \\
\hline Age (year) & 33 & 19 & 15 & 24 & 39 & 25 & 35 \\
\hline Neurological form & $\begin{array}{c}\text { limbic } \\
\text { encephalitis }\end{array}$ & $\begin{array}{l}\text { limbic and } \\
\text { brainstem } \\
\text { encephalitis }\end{array}$ & $\begin{array}{c}\text { limbic } \\
\text { encephalitis }\end{array}$ & $\begin{array}{l}\text { encephalo } \\
\text {-myelitis }\end{array}$ & $\begin{array}{c}\text { limbic } \\
\text { encephalitis }\end{array}$ & $\begin{array}{c}\text { limbic } \\
\text { encephalitis }\end{array}$ & $\begin{array}{c}\text { limbic } \\
\text { encephalitis }\end{array}$ \\
\hline \multicolumn{8}{|l|}{ Clinical symptoms } \\
\hline Impaired consciousness & - & + & + & + & + & + & - \\
\hline Dysmnesia & + & + & + & + & + & + & + \\
\hline Psychiatric symptom & - & + & + & + & + & - & + \\
\hline Seizures & - & + & - & - & + & + & - \\
\hline \multicolumn{8}{|l|}{ Cerebrospinal fluid } \\
\hline Cells $(\mu 1)$ & normal & 34 & normal & 23 & 65 & normal & 15 \\
\hline Protein (mg/dl) & normal & 19 & normal & normal & 64 & normal & 35 \\
\hline MRI abnormalities & N.D. & normal & normal & medulla & normal & $\begin{array}{c}\text { bilateral } \\
\text { hippocampi }\end{array}$ & normal \\
\hline Treatment & operation & operation & operation & $\begin{array}{l}\text { operation, } \\
\text { IVIg } \\
\text { steroid }\end{array}$ & operation & $\begin{array}{l}\text { operation } \\
\text { steroid }\end{array}$ & $\begin{array}{c}\text { steroid } \\
\text { operation }\end{array}$ \\
\hline Pathologic diagnosis & mature & immature & immature & mature & immature & immature & immature \\
\hline Sequelae & - & amnesia & - & - & $\begin{array}{l}\text { affective } \\
\text { disorder, } \\
\text { amnesia }\end{array}$ & $\begin{array}{l}\text { amnesia } \\
\text { seizure }\end{array}$ & - \\
\hline
\end{tabular}


tients improved after resection of the ovarian tumor. In this patient, we continued three courses of pulse therapy because of the elevation of IL- 6 in the CSF. Thereafter, symptoms in this patient improved significantly. Therefore we speculate that autoimmune mechanisms contributed to the encephalitis in this patient.

It is impossible to exclude the possibility that the tumor was a coincidental association and that the neurological syndrome was causally related to mechanisms other than paraneoplatic mechanisms. However, we were unable to demonstrate any infectious etiology and serological data suggesting a systemic vasculitis. Neurological symptoms and increasing tumor size presented simultaneously. Taken together, her clinical presentation, CSF profile, neuroimaging, detection of autoantibodies and elevated cytokine level argues strongly in favor of a paraneoplastic etiology.
In this patient, autoantibodies against GluRe2 and GluR $\delta 2$ were detected, although the tumor expressed no detectable GluR $\varepsilon 2$ or GluR $\delta 2$. These data suggest that autoantibodies to GluRs may be produced after neuronal injuries. Tumor immunity may induce activation of autoreactive cytotoxic $\mathrm{T}$ cells and produce cytotoxic cytokines etc, which may result result in neuronal damage. The data also suggest that an autoimmune mechanism against ovarian tumor may cross react with GluRs. Although the role of autoantibodies to GluRs is not clear, autoantibodies against GluR $\varepsilon 2$ (NMDA 2B) are reported to cause neuronal apotosis in hippocampal neurons (14). Therefore, autoantibodies to GluRs, even which are produced after some neuronal injuries may affect the symptoms of paraneoplastic limbic encephalitis. Additional cases are needed to elucidate the relationship between PLE and autoantibodies to GluR.

\section{References}

1. Dalmau J, Graus F. Paraneoplastic syndromes of the nervous system. In: Cancer of the Nervous System. Black PM, Loeffler JS, Eds. Blackwell Scientific, Cambridge, MA, 1997: 674-700.

2. Shoji H, Azuma K, Nishimura Y, Fujimoto H, Sugita Y, Eizuru Y. Acute viral encephalitis: The recent progress. Intern Med 41: 420428, 2002.

3. Asaoka K, Shoji H, Nishizaka S, et al. Non-herpetic acute limbic encephalitis: cerebrospinal fluid cytokines and magnetic resonance imaging findings. Intern Med 43: 42-48, 2004.

4. Takahashi Y, Mori H, Mishina M. Autoantibodies to NMDA receptor in patients with chronic forms of epilepsia partialis continua. Neurology 61: 891-896, 2003.

5. Hayashi Y, Matsuyama Z, Takahashi Y. A case of non-herpetic acute encephalitis with autoantibodies for ionotropic glutamate receptor delta2 and epsilon2. Rinsho Shinkeigaku (Clin Neurol) 45: 657-662, 2005 (in Japanese, Abstract in English).

6. Sillevis Smitt P, Kinoshita A, DeLeeuw B, et al. Paraneoplastic cerebellar ataxia due to autoantibodies against a glutamate receptor. N Engl J Med 342: 21-27, 2000.

7. Takahashi Y. Infections as causative factors of epilepsy. Future Neurology 1: 291-302, 2006.

8. Fadare O, Hart HJ. Anti-Ri antibodies associated with short-term memory deficits and a mature cystic teratoma of the ovary. Int Semin Surg Oncol 1: 11-13, 2004.

9. Nokura K, Yamamoto H, Okawara Y, Koga H, Osawa H, Sakai K. Reversible limbic encephalitis caused by ovarian teratoma. Acta Neurol Scand 95: 367-373, 1997.

10. Okamura H, Oomori N, Uchitomi Y, et al. An acutely confused 15-year-old girl. Lancet 350: 488, 1997.

11. Taylor RB, Mason W, Kong K, Wennberg R. Reversible paraneoplastic encephalomyelitis associated with a benign ovarian teratoma. Can J Neurol Sci 26: 317-320, 1999.

12. Aydiner A, Gurvit H, Baral I. Paraneoplastic limbic encephalitis with immature ovarian teratoma-a case report. J Neurooncol $\mathbf{3 7}$ : 63-66, 1998.

13. Munakata $S$, Nagumo $K$, Masaoka $N$, et al. Non-herpetic acute limbic encephalitis recovered before the growing of ovarian teratoma - Correlation with "paraneoplastic syndrome"Shinkeinaika 59: 112-116, 2003 (in Japanese).

14. DeGiorgio LA, Konstantinov KN, Lee SC, Hardin JA, Volpe BT, Diamond B. A subset of lupus anti-DNA antibodies cross-react with the NR2 glutamate receptor in systemic lupus erythematosus. Nature Med 7: 1189-1193, 2001.

(C) 2007 The Japanese Society of Internal Medicine http://www.naika.or.jp/imindex.html 